\title{
The Problems of Inflation and Pricing in Russia
}

\author{
Julia Jurevna Suslova ${ }^{1}$ \\ Elina Alexandrovna Batrayeva² \\ Marsel Dimekhametovich Batrayev³ \\ 1 Department of Trade Business and Marketing, Institute of Economics and Trade, Siberian Federal University, Krasnoyarsk, Russia \\ ${ }^{2}$ Department of Economics and Planning, Institute of Economics and Trade, Siberian Federal University, Krasnoyarsk, Russia \\ ${ }^{3}$ Department of Technology and Organization of Public Catering, Institute of Economics and Trade \\ Siberian Federal University, Krasnoyarsk, Russia \\ Correspondence: Julia Jurevna Suslova, 9/11, Krasnoy Armii Street apt. 31, Krasnoyarsk \\ Krasnoyarsk Region, 660017, Russia; E-mail: sokol-151@ya.ru
}

\section{Doi:10.5901/mjss.2015.v6n5s4p197}

\begin{abstract}
The article analyzes the causes of the inflation processes and pricing stages in the Russian Federation through the example of food products in the process of their promotion to the consumer market. The factors are identified, which influence the price level, and their influence is analyzed. The existing practice of the price constituents' formation is examined, which allowed to determining negative consequences of the lack of state control over the processes of prime cost calculation and justification in all links of the products flow, as well as for justification of rates offered by the monopolist enterprises and natural monopolies and justification of trade markups. The state's role in pricing is evaluated. The current pricing legislation of Russia is analyzed, which does not solve the price growth issues. A review of price adjustment experience and the existing legislative practice in this area in the European countries is provided. Patterns for pricing improvement are determined with account of the foreign experience and the business environment specificity.
\end{abstract}

Keywords: price, rate, pricing, inflation, prime cost, wholesale markups, trade markups, anti-monopoly legislation

\section{Introduction}

The main purpose of macroeconomic approaches to pricing is the evaluation of different patterns of the economic policy of advanced countries. The ability of the macroeconomic approach to forecast further situation development determined the basic parameters of the state budgetary policy, the change in the inflation processes, and the of macroeconomic models of their development.

One of severe problems of Russia in recent twenty years is the inflation processes embracing all economy sectors, including food products manufacture and sales. As it is known, inflation refers not only to the prices growth in certain economy sectors, but also continuous to the increase in the general price level in the country, which is determined by stable and long-term misbalance between the aggregate supply and demand. There are many causes of inflation and factors influencing its occurrence, namely:

1) Unjustified volumes of the state's monetary emission, not supported by a corresponding increment of the domestic production;

2) Reduction of domestic production outputs;

3) Increased burden of tax;

4) Decreasing rate of the national currency;

5) A low competition level and others.

The country size and different levels of the socioeconomic development of its constituent regions determine the difference in the inflation rates by periods in different regions of the country, which is evidenced by the data on the price growth for previous five years (Table 1). According to the table data, the consumer prices' index on the territory of the Krasnoyarsk region significantly differ from the rates of their increase across the country. In 2010, 2013 and 2014, the prices in the region in general grew less than in Russia, while in 2011 and 2012 the growth rates were higher. As for groceries, the price growth in the Krasnoyarsk Region in almost all analyzed years, except for 2011, was higher than the Russia's average. 
Therefore, the general stable trend of continuous price growth in the Russian Federation has become a distinctive feature of the domestic economy. Such situation results in a social strain and impedes normal economic development. Inflation processes on the groceries market, undoubtedly, have an objective ground determined by the general disequilibrium of the country's economy, but in our opinion, there are also other subjective causes, which consist in the state's non-participation in the pricing process in the country. The Government announced the principle from the classic economic theory-free pricing, when the prices are formed under the impact of the market environment, and the state authorities do not interfere into this process considering that the market and the competition will adjust everything by themselves. We believe that the concept of the market's absolute self-regulation has been rejected long ago by the experience of the state's interference into the pricing processes in advanced countries (Satcuk \& Suslova, 2014). Unfortunately, the reality of our economic management confirms existence of serious problems with regard to the presence and protection of free competition, and the common practice of pricing and public authorities and entrepreneurs' attitude towards this process does not contribute into the price level stabilization.

Table 1. Inflation rates in Russia and the Krasnoyarsk Region in 2010-2014 (Food inflation in Russia, http://economics guru.ru; Inflation: the Siberian Federal District, Russia, http:/lecon.krskstate.ru)

\begin{tabular}{ccccc}
\hline Years & $\begin{array}{c}\text { Inflation rates in the } \\
\text { Russian Federation, \% }\end{array}$ & $\begin{array}{c}\text { Inflation rates for groceries in } \\
\text { the Russian Federation, \% }\end{array}$ & $\begin{array}{c}\text { Inflation rates in the } \\
\text { Krasnoyarsk Region, \% }\end{array}$ & $\begin{array}{c}\text { Inflation rates for food products } \\
\text { in the Krasnoyarsk Region, \% }\end{array}$ \\
\hline 2010 & 112.9 & 108.8 & 107.9 & 110.7 \\
2011 & 103.9 & 106.1 & 106.1 & 105.9 \\
2012 & 107.5 & 106.6 & 108.8 & 108.5 \\
2013 & 107.3 & 106.5 & 104.8 & 106.2 \\
2014 & 115.5 & 111.4 & 109.5 & 113.8 \\
\hline
\end{tabular}

Active discussion of the problems of general pricing and pricing for groceries and agricultural products (raw materials) in particular, as well as certain attempts to solve them by public authorities are initiated only when a rapid price growth and negative reaction of the society to it occurs-as it happened in autumn of 2011, summer of 2013, and at present time. Along with that, as the practice shows, as far as some price growth stabilization takes place, the state loses its interest in this issue until the next inflation outburst.

\section{Literature Review}

Modern native and foreign sources of scientific literature dedicated to the pricing issues focus on the costs of manufacturing companies. At the same time, the pricing methods, the costs and profits of companies are different depending on business economic environments in different countries.

In the Russian Federation, a range of legal and statutory documents, including the Civil and Tax Codes, federal laws and subordinate acts are used to cope with the pricing issues. The authors have applied the approach of generalization and identification of the pricing problems in the circumstances of monopoly, prime cost formation, and price adjustment in Russia and abroad.

\section{Method}

In order to identify the reasons of the continuous price growth and the state's role in this process, it is necessary to understand the logic of pricing for the native groceries, and for this purpose, firstly, monitor all stages of pricing in their movement from agricultural manufacturers to retail distribution networks; secondly, to evaluate the legal and statutory basis of pricing in the country, as well as the state's role and actions in this field.

Let us consider this issue through the example of such large Russian region as the Krasnoyarsk Region located on the territory of 2366.8 thousand sq.km, which has quite developed agriculture (over 3,400 enterprises) and food production, i.e. is able to produce large volumes of food supplies (Krasnoyarskstat, 2014).

Agricultural manufacturers of the Krasnoyarsk Region are dispersed on the large territory away from the processing and food production enterprises and large cities. Therefore, the process of food materials supply to the processing units and population is of multi-stage nature due to the objective causes. Pricing is performed in the process of food materials and products movement to the consumer's market, when each stage of the product flow forms its own price. 
Graphically, the standard scheme of this process in the region, as well as the pricing and price structure are shown in Figure 1. The scheme does not show indirect taxation, because taxes are automatically included in the structure of price (Federal Law of the Russian Federation 2008, 2013).

Thus, the final price of domestic food products in the regional consumer market depends on three factors:

- Expenses of each participant of the products promotion - the prime cost of the food products, which includes not only the expenses of agricultural producers and food and processing enterprises, but also the cost of services of trade organizations (supplying, wholesale, retail), i.e. the distribution costs, which we shall consider as the cost of intermediary and trade services;

- The amount of the profits earned by all the participants of distribution process;

- The number of participants of the distribution process, i.e. the number of intermediaries.

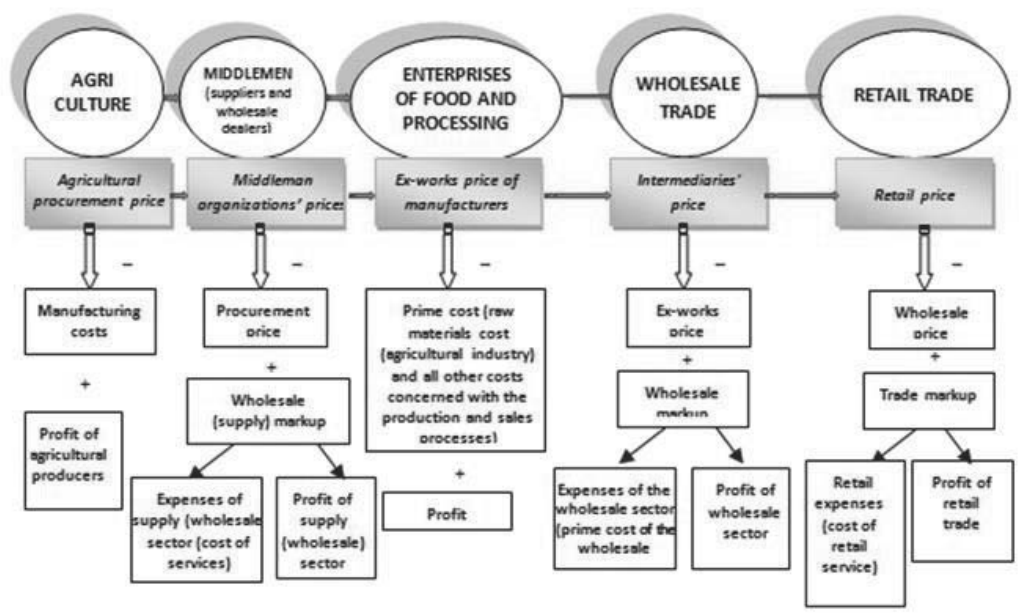

Figure 1. The scheme of food products' pricing

Below there is an analysis of the price elements formation.

As shown in the Figure 1, the basis of the price and its important element is the costs that are called the unit prime cost in the Russian legislation-in agricultural and manufacturing industries, or the distribution costs-in the intermediary, wholesale, and retail trade organizations.

The prime cost value depends on the following factors:

- The structure of expenses included in the prime cost, their expediency, and validity of their amount;

- The physical volume of resources used for production and sale of a product unit;

- The production and sales volumes;

- The prices, rates and tariffs for used material, labor, and financial resources and services.

The Russian legislation regulates the structure, but does not reflect the limit of expenses included in the prime cost. In practice, enterprises and organizations include all actual costs of the company: high salaries of the administrative and management personnel with respective insurance premium payments to non-budgetary funds; unreasonable expenses on transport maintenance, and various kinds of losses; high administrative expenses. Restrictions on the expenses are taken into account when calculating the profit tax, but they apply only to a few items-advertising expenses (partially), hospitality expenses, expenses for voluntary life insurance and voluntary insurance of medical expenses of employees, expenses for provisioning for doubtful debts.

\section{Results}

\subsection{Problems of Prime Cost Formation}

The country's agricultural industry and many food manufacturing and processing enterprises have excessive resource 
intensity of food production compared to Western countries due to the use of outdated technology, lack of modern machinery and equipment, as well as a relatively low level of labor performance, which also contributes to the costs increase.

In addition, when calculating the prime cost, the fluctuations of its value due to the changing scale of production caused by the heterogeneity of the expenses are not taken into account: the presence of conditional-fixed and conditional-variable costs reduces the actual prime cost per unit during the growth of production volumes in comparison with the planned indicators and increases it with the decrease of production volumes. In practice, economic and accounting departments of companies are not engaged in detailed calculations and justification of the cost when some production conditions or the range of activity change. For example, there was a growth in the raw materials, products, and goods output. This automatically reduces the unit prime cost, but in the process of price justification, these changes are not taken into account, and the goods continue to be sold at the prices set for the planned production volume.

In modern conditions, when on the part of government, there are no price restrictions, and control over the costs is insufficient, all participants of the production process, product distribution agents, and trade enterprises are not interested in searching and applying the opportunities to reduce the prime cost and expenses for the purpose of increasing or maintaining the profit gained. It is much easier to include all the expenses in the prime cost and automatically raise the prices justifying this by the increase in expenses. According to economic calculations, when the cost grows, the price also increases, but certainly at a slower pace than the cost (Bazdnikin, 2014; Lipsitz, 2012).

Another important factor affecting the level of the prime cost (costs) are the prices (tariffs) for the services of energy resources suppliers and transport companies. Due to the climate peculiarities and the territorial factor, these costs represent a significant part in the cost and expenses structure of Russian enterprises. At the present moment, in accordance with the Russian legislation, suppliers of resources (fuel, gasoline, electricity, gas) are regarded as natural monopolies, or as companies that have a dominant position in the market, i.e. monopolies. Therefore, prices and rates for their goods and services in accordance with the Federal Law of the Russian Federation and the Orders of the Government of the Russian Federation are regulated. They are set and approved by the relevant regional or federal committees with the involvement of public authorities.

Firstly, the rates setting procedures for practically all energy carriers are opaque. They are set by expertise based on economic data, calculations, and arguments to justify rates, provided by the monopolists. The information on who and how checks the accuracy of the data provided, their validity, what expenses exactly and in what amount are included in the calculation, is a sealed book. Since rates are the price for resources or services, which consists of costs and profits, all of the above disadvantages of cost formation are inherent in them either. That allows us to state the fact of absence of such an important concept for pricing as economic justification of expenses (costs) in the Russian practice of pricing.

Secondly, the amount and share of profit in the tariff is absolutely unknown, and the principle of its justification is unclear: according to energy resource suppliers and control organizations, the annual constant tariff increase is caused by the need of investments in these areas of activity, especially in electric power industry, but the system of their calculation itself, as well as the share of investment costs in the tariff are not disclosed, and there is no information on the use of funds received. According to the majority of Russian entrepreneurs, one of the main obstacles to their development is a very high level of energy rates.

\subsection{The Role of Intermediary Organizations in the Prices Increase}

Services supply and sale systems of monopolists include intermediaries, which is also quite an interesting fact. For example, the electricity market in Russia is also split and sale of resources is performed in stages via intermediate links and different channels: from the manufacturers selling energy source to an intermediary, and the latter- to another intermediary or to the end consumer. Along with that, the necessity of existence of several stages of electric energy reselling casts some doubts among clear-headed specialists. The number of the intermediaries is not limited by any documents, and it is not clear who they are- intermediary organizations are often created artificially and function under the control of the manufacturers themselves for additional profit gaining. It is reasonable that the existing mediation system automatically increases the level of the rates, since each intermediate link in the supplies chain resells the resource at a higher price, adding wholesale markup and gaining profit (Mankiw \& Taylor, 2013; Shulyak, 2012)

In such a way, quite a paradoxical situation was created in the sphere of domestic pricing: The services of the monopolists are consumed by all economy sectors. Therefore, their rates growth approved by the state authorities results in the prime cost growth for all goods, products, works and services in the country. It appears that the state permanently expressing its concern in the price growth encourages this process for many years.

According to the majority of economists, continuous growth of the natural monopolies' rates is the core reason of 
the inflation processes in the country.

The second factor having an impact on the level of prices is the profit obtained by each participant of the products flow, either in the net form or as a part of wholesale and trade markups in the intermediate and trade organizations. The share of the profit in the price (except enterprises registered in the monopolists register) is virtually limited by nobody and nothing, except for the right granted according to Decree of the Government of Russia, 2013: executive authorities of the constituent entities of the federation are entitled to regulate such an indicator as the profitability level determined as percentage of the transport organizations' costs. For the enterprises dominating on the market, a separate procedure of prices justification and approval is provided in accordance with the Federal law "Concerning competition protection", 2013. As for the amounts of the wholesale, supply-and-sale, and trade markups-the situation with their state regulations is as follows.

In accordance with the Decree of the Government of Russia, 2013, issued in execution of the Order of the President of Russia, 2013, the executive authorities Russian regions can implement state regulation of the amounts of wholesale, supply-and-sale, and trade markups for the products and commodities sold in the Far North regions; markups on the products of public catering enterprises in educational institutions; trade markups on baby food products, including food concentrates.

The Federal Law "Concerning principles of state regulation of the trading activity in the Russian Federation", 2009 provides recommendations regarding limiting trade markups' amount for staples. Given the non-mandatory nature of such recommendations, they can be followed (and followed by some representatives of the distributive networks under agreement with the administrative authorities) or ignored, and the overwhelming majority of trade organizations do not take them into account. Article 8. 5. of this law determines that in case the retail price in a certain country region for any socially important staple increases by $30 \%$ or more within one month (30 days), the Government of Russia will be able to establish marginal prices for such staples within the region for the period of up to 90 days for the purpose of price stabilization, 2009. However, the law does not specify the manner, in which the violations are identified and registered and who and in what manner is to make this information known to the Government, i.e., the principle has been established, but no real mechanism of its implementation has been developed. Besides, the value of the allowed growth (30\% per month) is not clear. A legitimate question arises: Who determined it and why is it so high? For instance, in case the price of a standard loaf of bread is equal to 24 rubles, then the issue on the price adjustment will be considered only in case the price will grow up to 31.2 rubles and higher within one month. From our point of view, even if the price will grow by $5 \%$ within a month, this fact must become a matter at issue.

Therefore, the real market situation has been developed in such a way that food products can be sold for any free prices established by trade enterprises, since state regulation of prices is not applied for such products, and owners and managers of trade enterprises use it for their own benefit.

For the many-years period of market transformations and complete absence of control over price growth, a certain pricing psychology has developed in the Russian business, the essence of which is that any price can be increased at any moment, and it will not produce any adverse impact on the business. Besides, Russian entrepreneurs have got used to highly profitable business and will not change their vision voluntarily. The logic of their actions does not suggest the possible decrease in profit and profitability as the cost constituent of the price increases, and they prefer to make consumers pay for it (Makhovikova \& Lizovskaya, 2014).

The third factor contributing to the growth of prices for the products is the earlier described situation-the existence of intermediate links in the process of food products movement to the consumer's market, i.e. numerous resellers. For many years, a layer of entrepreneurs has formed, through which products and goods are distributed, since there are no limitations of their quantity, borders of the possible prices increase, limiting amounts of the wholesale and intermediaries' markups.

As a result, intermediaries directly influence on the price growth, gaining unjustified profit by means of artificial increase of the number of products flow links. By all means, wholesale trade is necessary, it performs a range of functions, but it is obvious that intermediaries' activity is to be limited somehow-it primarily concerns the way of movement of the food resources and domestically manufactured goods i.e., agricultural and food production in the Krasnoyarsk Region.

\section{Discussion}

\subsection{Disadvantages of the Existing Legal Frameworks of Price Control}

Discussing the above-specified information, we shall note that the existing practice of the state's virtual aloofness from 
the processes of pricing control has failed to be effective. The thesis that the market economy will adjust everything by itself does not work.

There are many reasons for that, and the most important of them is the imperfection of pricing determined by the absence of any clear, logical, and justified policy of pricing. In our view, development of an economically justified and well-planned system of state regulation of prices and control over their development, which would contribute to normal operation of honest entrepreneurs and would not allow speculators and monopolists to boost prices at their own discretion and without any punishment, must become a constituent element of such policy.

Firstly, Russia lacks a uniform pricing course, a uniform state price policy, which would combine organically the pricing issues in different branches and spheres, link with each other and line up in such a manner as to contribute to progressive development of the economy in general and to fulfillment the populations' interests. Secondly, there is no uniform legislator act concerning pricing issues in Russia, which is caused by the first cause.

Currently, the issues of pricing in the country are regulated by different legislative and statutory acts: Orders of the President of Russia, the Tax and Civil Codes of Russia, Decrees of the Government of Russia. Certain pricing issues are addressed by federal laws concerning development of natural monopolies and monopolist enterprises, based on which laws corresponding Decrees of the Government of Russia have been adopted. Besides, there are various institutional subordinate and statutory acts, the information about which is usually confidential. This complicates the analysis of the existing situation in the pricing sphere, slows down the process of the state's influence on prices, causes contradictory pricing in different spheres, and does not allow to perform complete control over the fulfillment of even effective orders and decisions.

\subsection{Review of the Foreign Experience in Price Control and the Possibility of Its Application in Russia}

For many years, foreign countries have accumulated vast experience on price control. This price control should be analyzed and the possibilities of its partial application in Russian should be revealed (Arbatskaya, 2001; Chen, 1995; Moorthy \& Zhang, 2006).

An analysis of pricing for the products and services in European countries shows that the governments of such countries actively interfere into the economy management processes, and one of the main regulation objects is pricing. Its legal framework is continuously improved depending on the market environment. The forms and methods of influence and the degree of control differ in various countries and depend on the country's economy peculiarities. In general, according to mass media, the share of regulated prices is as follows: Austria-10\%, Greece-20\%, France-20 \%, Japan-20\%, USA-5-10\%, Spain-10\%, Denmark-6 \%, Switzerland-up to $50 \%$ of prices for the food products (Figure 2) (Shulyak, 2012).

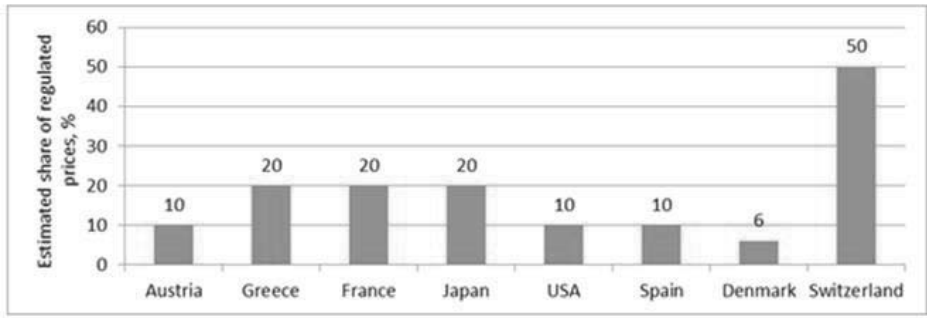

Figure 2. The estimated share of regulated prices in foreign countries

Firstly, foreign countries have developed pricing legislation, as well as laws regulating the scope of state control of pricing and the methods applied to their control. A list of products, commodities, works, and services has been determined, the prices for which are controlled by a certain state body. It also determines the authority of ministries and agencies engaged in price control. A mechanism of price control and prevention of their growth has also been developed (Lev, 2009; Kaplan, 2000).

Secondly, the legal framework of such countries does not only regulate the pricing issues, but is also focused on maintaining and protecting the competitive environment and struggling manifestations of monopolies, since these countries have serious and effective anti-monopoly legislation allowing to suppress any monopoly symptoms. 
Thirdly, such countries apply (or their legislation determines) the possibility of the direct administrative interference into the pricing process by different methods in cases, when an administrative body decides that it is required by the market environment, such as: establishment of the fixed prices; establishment of the marginal prices; establishment of the limitations for profit and markups amount; establishment of the possible prices coefficients; introduction of prices freezing (Coughlan, 2009; Dugar, 2007).

As a rule, the legal framework if formed so that in any unfavorable price growth, no additional permits for price adjustment are required. Most often, the head of the economic bloc in the government is entitled to introduce price adjustment at any moment in case of their unjustified growth.

Fourthly, all countries have effective control over the compliance with the pricing legislation, and in case of its violation severe economic sanctions are applied, to which end the corresponding prices control authorities have been established. Their functions are different in different countries, but the common tendency also exists:

- Monitoring prices development;

- Imposing sanctions in case of violation of the pricing legislation;

- Verifying rationale of price increase petitions;

- Justifying the prices change value, etc.

Fifthly, in many countries there are systems of agreement between state authorities, manufacturers (associations of manufacturers), and the society representatives for price increase or change issues. For example, Austria has the Parity Prices Commission, Greece has the Advisory Price Committee, Belgium has the Price Adjustment Committee. They consist of both entrepreneurs and representatives of ministries (Shulyak, 2012).

\section{Conclusion}

Thus, the experience of foreign countries evidences that price control and interference into pricing processes do not contradict the market economy laws, but, on the contrary, contribute to its development and safeguard the interests of both entrepreneurs and the population.

The modern market economy needs active economic involvement of the government. Almost all foreign countries have mechanisms of state interference into the economy, though their forms, tolls, and levers sometimes considerably differ. The majority of countries apply the established rules of pricing, which are documented in the form of statutory acts regulating the procedure and methods of pricing. Studying the pricing experience in foreign countries is required in order to understand how it can be applied in the formation of the pricing mechanism in our country.

Modern state control of prices in foreign countries is quite controversial. On the one hand, state institutions aim to slow down inflation affecting both the domestic and external economic processes. On the other hand, expressing the interests of large companies, the state protects them by different means. In the result, the control is an attempt of the state to influence on prices by means of legislative, administrative, budgetary, and financial measures in order to maintain stable development of the economy in general and, through the prices, to dampen fluctuations occurring in the reproduction process.

State interference into pricing is implemented based on a combination of forms of direct and indirect regulation. The control degree and the proportion of these forms depend on the level of the country's economic development, national traditions, political environment, availability of raw materials resources, the country's position in the global labor division, etc.

Measures for pricing improvement must be primarily developed on the level of the Russian Federation in general, since the existing legislation does not allow the authorities to interfere into such processes.

Therefore, the focus areas of the work must be:

- Improvement of the entire pricing system within the framework of development and adoption of a corresponding basic Federal Law on prices determining general principles, targets, and objectives of the state pricing policy in the territory of Russia.

- Development of a mechanism of pricing policy implementation and control over its observance.

- Introduction of amendments and supplements into the effective legislation to strengthen the role and extend the power of regional public authorities with regard to pricing for food products and their justification.

- Extension of the state regulation scope-introduction of price control for socially important essential commodities on the regional level by means of, for example, establishment of marginal wholesale markups for domestic agricultural products, which will contribute to excluding unnecessary intermediaries from the products flow. 
- Strengthening the control over the structure of expenses included into the prime cost, limitation of the amount of some expense items, which will allow not to increasing products prime cost by including non-productive costs.

- Improvement of pricing of monopolist enterprises and natural monopolies by means of development and putting into practice the concept of "economically feasible costs," engagement of independent experts into their formation, which will allow to control the prices and prevent their unjustified growth.

- Further improvement of the anti-monopoly legislation and creation of a more effective mechanism of control over its observance.

- Introduction of more severe liability for violation of the state pricing discipline.

- Establishment of authorities for price control, assigning corresponding authority to them, engaging public organizations to price monitoring and control over observance of the state price regulation.

Implementation of these proposals will contribute to the price growth stabilization, which will have a positive impact on the economy health and the psychological environment in the society.

\section{References}

Arbatskaya, M. (2001). Can low-price guarantees deter entry? International Journal of Industrial Organization, 19, 1387-1406.

Batrayeva, E. A. (2012). Reasons of food products prices growth and ways of their overcoming. Economy. Psychology. Business. Regional Inter-university Journal. Krasnoyarsk, 21, 52-59.

Bazdnikin, A. S. (2014). Price and pricing: handbook and case study. Finance University of the Government of Russia (pp. 370). Moscow: Uright.

Chen, Z. (1995). How low is a guaranteed-lowest-price? Canadian Journal of Economics, 28, 683-701.

Civil Code of the Russian Federation in 4 parts: As of April 1, 2013 (p. 512). Moscow. Eksmo.

Inflation: Siberian Federal District, Russia. Retrieved from http://econ.krskstate.ru///ser_kray//potrebrynok//inflation//inf/

Federal Law of the Russian Federation “Concerning competition protection" dated 26. 07. 2006 \#135-FZ (as amended on 28.12.2013).

Decree of the Government of the Russian Federation "Concerning measures for adjustment of the state prices (rates) regulation" dated 07. 03. 1995 \#239 (as amended on 09. 03. 2013).

Order of the President of the Russian Federation "Concerning measures for adjustment of the state prices (rates) regulation" dated 28. 02. 1995 \#221 (as amended on 08. 04. 2003).

Federal Law of the Russian Federation "Concerning natural monopolies" dated 17. 08. 1995 \#147-FZ (as amended on 25. 12. 2008).

Decree of the Government of the Russian Federation Concerning pricing in the area of regulated prices (rates) in the electric power industry" dated 29. 12. 2014 \#1178 (as amended on 17. 02. $2014 \# 117$ ).

Decree of the Government of the Russian Federation Concerning pricing in the heat supply area" dated 22. 10. 2012 \#1075 (as amended on 07.10.2013 \#886).

Federal Law of the Russian Federation "Concerning principles of the trading activity regulation in the Russian Federation" dated 28. 02. 2009 \#381-FZ.

Federal Law of the Russian Federation "Concerning State Regulation of Rates for Electrical and Thermal Energy in the Russian Federation" dated 10 .03. 1995 (as amended on 27. 07. 2010).

Coughlan, A. T., \& Shaffer, G. (2009). Price-matching guarantees, retail competition, and product-line assortment. Marketing Science, $28,580-588$.

Dugar, S. (2007). Price-matching guarantees and equilibrium selection in a homogenous product market: An experimental study. Review of Industrial Organization, 30, 107-119.

Food inflation in Russia. Retrieved from: http:/leconomicsguru.ru/inflyacziya/inflyacziya-na-osnove-indeksov-potrebitelskix-czen/ prodovolstvennaya-inflyacziyal

Kaplan, T. (2000). Effective price matching: A comment. International Journal of Industrial Organization, 18, 1291-1294.

Lev, M. Y. (2009). State price regulation in the foreign countries (p. 423). Moscow: UNITY-DANA.

Lipsitz, I. V. (2012). Pricing: Workbook (p. 399). Moscow: Uright.

Makhovikova, G. A., \& Lizovskaya, V. V. (2014). Pricing in trading activity: Textbook (pp. 231). Moscow: Uright.

Mankiw, N. G., \& Taylor, M. (2013). Macroeconomic (p. 559). Saint Petersburg: Piter.

Moorthy, S., \& Zhang, X. (2006). Price matching by vertically differentiated retailers: Theory and evidence. Journal of Marketing Research, 43, 156-167.

Satcuk T. P., \& Suslova, J. J. (2014). Assessment of qualitative indicators in a balanced system of indicators. Life Science Journal, $11(7 \mathrm{~s}), 417-422$.

Shulyak, P. N. (2012). Pricing: Workbook (p. 192). Moscow: Dashkov \& Co.

The Krasnoyarsk region in figures-2013. (2014). Brief statistics digest (p. 158). Krasnoyarsk: Krasnoyarskstat. 